\title{
Empowering Contextual Approach in Science Learning to Enhance Critical Thinking Skills:
}

\author{
Some Cases of Learning Science at Secondary School
}

\author{
Bibin Rubini*, Didit Ardianto \\ Science Education program \\ UNPAK \\ Bogor, Indonesia \\ *bibinrubini@unpak.ac.id
}

\begin{abstract}
This study aims to investigate the role of contextual virtual lab, contextual-based module, and contextual-based articles in enhancing critical thinking skills of junior secondary student. The learnings were arranged for three contexts: (1) How the heart pumps blood throughout the body (virtual lab based); (2) How the nutrient fluid can get to the top of the tree (article based); and (3) How to maintain our environment (textbook based). All topics were implemented in 8th grade students of three parallel classes consisted of 30 students. The research shows that the implementation of contextual learnings has the potential to improve critical thinking skills for the three forms of media used. The improvement in all three classes occurred in the fair category. Some developed critical thinking skills were providing simple explanations, building basic skills, managing strategies and tactics, providing further explanation, and formulating solutions.
\end{abstract}

Keywords-critical thinking skills, contextual approach, learning media

\section{INTRODUCTION}

Critical thinking skill is one of modalities that has to be owned by student for facing the development of science and technology in this era. A person's ability to be successful in life is depend on the ability to think, especially in solving life problems [1]. Besides, by using critical thinking skills, student can be able to solve the problems in higher level [2]. Hassoubah stated that critical thinking skills is a thinking with reasoning and reflective to make a decision about what should be believed and done [3]. Moreover, Fisher stated that critical thinking is an evaluative thinking involving relevant criteria in order to access information with accuracy, relevancy, reliability, consistency, and bias [4].

Ennis stated that critical thinking is a reasoning skill and reflective thinking that is directed to make a decision should be done [5]. Meanwhile, Santrock stated that critical thinking is a reflective and productive thinking involved evaluation of proof [6]. Jensen argued that critical thinking leads to an effective and reliable mental process, use in the pursuit of the correct and relevant knowledge [7]. Proulx also implied that critical thinking is a mode of thinking that recognizes any matter, substance or problem where the thinker improves the quality of his thinking by skilfully handling the structures inherent in thinking and applying intellectual standards [8].

Some researchers argued that critical thinking includes disposition or processes in seeking truth and understanding, being strategic, and being sceptical, as components of critical thinkers [9]. Johnson also states that critical thinking is a clear and organized processes used in mental activities such as problem solving, decision making, persuasion, assumption analysis, and scientific inquiry [10-11]. Based on the description it can be concluded that critical thinking is a highorder thinking skill that student must master to solve the problem, gain higher knowledge and involve cognitive processes. Therefore, someone who has critical thinking skills can use it to carry out analysis, synthesis, and evaluation on using the knowledge he already has.

Critical thinking, as it is stated by Dahar, will develop maximally if it is supported by the conceptual understanding. Understanding concept means ability of student to comprehend knowledge scientifically and practically [12]. Facione argued that critical thinking is the understanding of student to use concepts, principles, and its nature [13]. A student has a conceptual understanding if he can be able to define, identify, and provides example and non-example with his own words. With his mastery, student can be able to recognize and calculate as well as to state the correct and incorrect answer, as well as he can be able to propose idea, to demonstrate it, to communicate orally and in writing. Study performed by PISA and TIMSS showed that the weaknesses of Indonesia student in understanding science concepts. Moreover, the lower achievement is shown in applying science concept to solve the problems [14,15]. It can be inferred Indonesia students are less skills in higher order thinking skills.

The empirical study shows that critical thinking skills can be developed in science learning which is implemented in the integrated learning such as threaded model on using level of 
inquiry learning [16], learning science with interactive problem based modul [17], learning with scientific approach [18], and guided inquiry [19]. Critical thinking can also be enhanced on using conflict cognitive [20] and problem-based learning [21,22], as well as on using project-based learning [23] and discovery learning [24].

Contextual approach is one of the approaches that being a concerned by the researcher. The approach can be able to enhance critical thinking skills of student as well as can make the student closer to problems in everyday life. Student can be a problem solver for their environment. The research shows that contextual learning can enhance critical thinking skills as well as concept understanding of student [25].

As in Rubini research report [26], contextual learning (CTL) can be able to start with the presentation or orally discussion that performed friendly, open, and negotiated, about the real world. By this starting, student will find it helpful to learn more, and so student learning motivation will emerge. During learning, the world of students' thoughts becomes concrete. Thus, the learning atmosphere will become conducive, comfortable and enjoyable. Students' activity is the principles in CTL. Students are doing, experiencing, observing, measuring, taking notes, and socializing to each other.

How can critical thinking can be taught to secondary student? One of the ways is by using media as a tool for enhancing critical thinking is very relevant to investigate. Some medias can be used in corporate with the CTL, such as IT. The development of information and technology currently have had a tremendous impact, including on learning. The use of ICT based media is now becoming increasingly popular. Various innovation has been made, one of which is interactive multimedia (IMM). IMM is the best solution for learning more efficiently, safely, and economically without neglecting thinking processes [27]. MMI is also the best media to use in online learning during the covid-19 pandemic. Based on the research, Puspita explained that virtual lab is a MMI in science learning that can be chosen instead of real laboratory [28]. Scheiner stated that: a virtual laboratory is a heterogeneous distributed problem-solving environment that enables a group of researchers located around the world to work together on a common set of projects [29].

Virtual lab IMM can be used to focus student attention to learning activities as well as to train student doing the lab work processes [30]. Virtual lab IMM is also useful to replace the real lab activities with high levels of danger [31]. Besides IMM, an effective media to accompany a contextual approach is articles downloaded from various information media and electronic learning module. Learning module are books that are prepared for the benefit of learning process, and are arranged systematically following the pedagogic principles. Learning module can be provides in electronic or printed version.

Based on the description above, the research was conducted to investigate the role of contextual virtual lab IMM, contextual-based module, and contextual based articles in enhancing critical thinking skills of Junior secondary student.

\section{MEthods}

The method used in the research was quasi experiment with pre-post test control group design [32,33]. The control group was threated with inquiry based learning without context. Each class was threated with twice meeting each 45 minutes.

The three classes were used as experimental class. All of experimental classes were threated with inquiry science learning on using different media with the different context. Each class consisted of 30 students. In the first class (Class C1 ), we used virtual lab based as a media, with the context of "How the heart pumps blood throughout the body?" In the second class (Class C-2), we choosed articles with context of "How Nutrient goes to the top of the tree?" In the third class (Class C-3), the learning module was with context of "How To maintain our environment?. The same subject were applied in the three control classes on using scientific inquiry approach without contexts. The assumption used in the research of which the three contexts used were close related to students' daily life and in the similar level in both of content and skills those can be trained.

\section{RESULTS AND DISCUSSION}

The research involved three science teachers with the same level of qualification (bachelor degree of sceinec education), teaching experience (5 years experience), and have got the teacher sertificate. Before implementing the learning, they did the workshop with the research team to have same perception toward lesson plan those will be implemented. The three science teachers were also conducted the learning in the control class with the same topics as they did in the experimental class, without using media. Based on observations, most of the steps of learning were done well by all of teachers. All of the scenario were implemented inline with the schedule.

Based on characteristic of topics, its essensial competencies, and its learning outcomes, the 5 indicators of critical thinking were developed along the learning, and then assessed after the learning. The 5 indicators were simple explanation, building basic skills, managing strtegies and tactics, providing further explanation, and formulation solution.

The research shows that contextual learning on using media can improve critical thinking skills of student in all of the three classes. The improvement in all of three classes were in the fair cathegory in average. This is inline with previous researches that contextual learning will leads to the easier of student in understanding concepts, so they can confidently solve the problems and put forward their critical thinking to provide arguments $[25,26]$.

The achievement of students' critical thinking skills in the three classes is elaborated in more detail in Tabel 1 and Figure 1. It was shown that proposing basic explanation of student are high in category with the $\mathrm{N}$-gain more than $50 \%$. This is meant that most of student in all of class has already performed the good answer for the question. The question was about asking for student explanation about why the blood tension of ones 
can be higher than others? why the nutrient can go to the top of tree? why foods always occurs in our area?. Meanwhile, the enhancement of other indicators mostly in fair category with the $\mathrm{N}$-gain are in balout $40-49 \%$. This can be understood because the higher the level of critical thinking requiring the more complex answer.

TABLE I. The ENHANCING CRITICAL THINKING OF STUDENT AFTER SCENCE LAERNING ON USING MEDIA (VIRTUAL LAB IN Class C-1, ARTICLES IN CLASS C-2, AND LEARNING MODULE IN CLASS C-3)

\begin{tabular}{|c|c|c|c|}
\hline \multirow[t]{2}{*}{ Indicators } & \multicolumn{3}{|c|}{$\begin{array}{c}\text { Cathegories } \\
\text { (Based on N-gain) }\end{array}$} \\
\hline & \begin{tabular}{|c|}
$C-1$ \\
\end{tabular} & $\begin{array}{ll}C 2 \\
\end{array}$ & $\begin{aligned} C 3 \\
\end{aligned}$ \\
\hline Proposing Simple Explanation & High & High & High \\
\hline Building Basic Skills & Fair & Fair & Fair \\
\hline Managing Strategies and Tactics & Fair & Fair & High \\
\hline Providing further explanation & High & Fair & Fair \\
\hline Formulating Solution & Fair & High & Fair \\
\hline
\end{tabular}

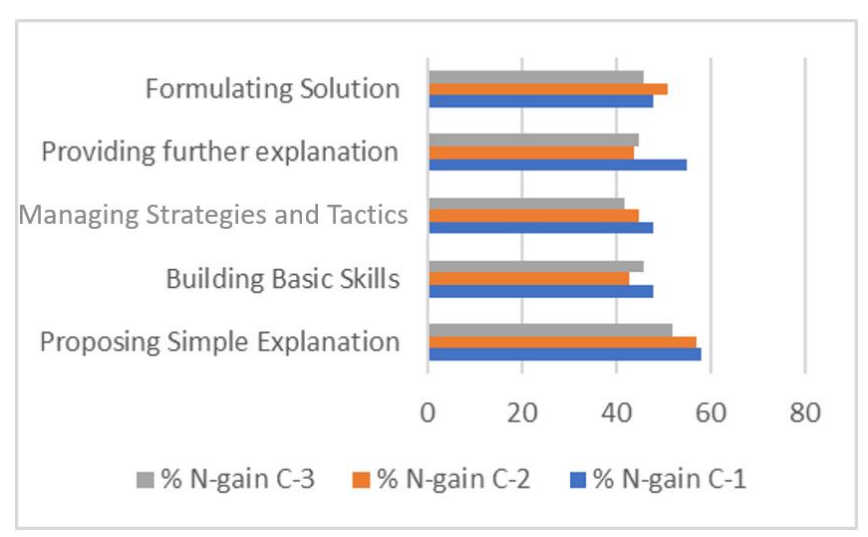

Fig. 1. The trend of enhancement of critical thinking skills of student after contextual learning on using media.

The enhancement of most of indicators was achieved by Class C-1 which has implemented virtual lab media in learning "How the heart pumps blood throughout the body" theme. This is explained by Ferreira et. al. [27], that virtual lab is the answer for building the meaningful learning. Moreover, Schneider [29], and Manisha [31] were also stated that the use of virtual lab can build the critical thinking of student if it is arranged on the right track.

Although the use of article and learning module are not as good as virtual labs, basically the use of these two media can also recommended if the virtual lab is not available. The article and learning modules related to contemporary issues make students interested in studying more deeply so that along the learning, the critical thoughts can be generated.

The other result shows that the enhancement of critical thinking of student in virtual lab-class was inlined with the student motivation. The learning motivation of student were in good and very good categories (Table 2). It is shown that student felt happy learning science with the media. The media allows students to easily learn how blockages of blood vessel occurs. They can also think the idea how to handle the blockages. The other advantage of using the media is that it can be operated independently, so student can bring the media and study it at home. As it is stated by Krathwohl [34], the innovative learning will lead to the high achievement of cognitive level. This is means that the learning will goes to the higher order thinking skills.

TABLE II. STUDENT MOTIVATION ON LEARNING SCIENCE THROUGH CONTEXT WITH VIRTUAL-LAB MEDIA

\begin{tabular}{|c|c|c|c|c|c|}
\hline No & Indicators & Score & $\begin{array}{c}\text { Max } \\
\text { Score }\end{array}$ & $\%$ & Category \\
\hline 1 & $\begin{array}{l}\text { The media is } \\
\text { relevant to the } \\
\text { learning }\end{array}$ & 115 & 128 & 90 & VG \\
\hline 2. & $\begin{array}{l}\text { The media easy to } \\
\text { operate }\end{array}$ & 112 & 128 & 88 & VG \\
\hline 3. & $\begin{array}{l}\text { The performance of } \\
\text { picture and } \\
\text { animation } \\
\text { interesting }\end{array}$ & 112 & 128 & 88 & VG \\
\hline 4. & $\begin{array}{l}\text { Using media need } \\
\text { skills }\end{array}$ & 101 & 128 & 79 & G \\
\hline 5. & $\begin{array}{l}\text { The media make me } \\
\text { understand toward } \\
\text { concepts }\end{array}$ & 118 & 128 & 93 & VG \\
\hline 6. & $\begin{array}{l}\text { I can handle the } \\
\text { media by my self }\end{array}$ & 116 & 128 & 91 & VG \\
\hline 7 & $\begin{array}{l}\text { I enjoy learning } \\
\text { science with the } \\
\text { media }\end{array}$ & 112 & 128 & 88 & VG \\
\hline \multicolumn{4}{|c|}{ Average } & 88 & $G$ \\
\hline
\end{tabular}

The use of virtual lab seems to give the student a distinct impression. Most of student in the class with virtual lab said that they were very enjoy learning with virtual lab, because it is very easy to operate, so they can handle it by themselves. More over the student said that the context used in virtual lab was very relevant with the concept learned. The performance of picture and animation in media made them understand the concept. This is in line with Salam et.al stated that virtual lab in science learning can improve the conceptual understanding [35]. It can be concluded that using virtual lab IMM in learning science will lead to the higher achievement of critical thinking skills, because of the learning is packaged in context and presented in an attractive and interactive manner.

\section{CONCLUSIONS}

Based on the results, it can be concluded that science learning on using context embedded in virtual lab, context-based article, as well as context-based learning module can effectively enhancing critical thinking skills of $8^{\text {th }}$ grader. The enhancement of critical thinking skills was in fair category in average. The use of virtual lab shows the best enhancement in critical thinking skills, more than the use of articles as well as learning modules. 


\section{ACKNOWLEDGMENT}

We thank to School of Postgraduates Studies Universitas Pakuan for funding the research and conference.

\section{REFERENCES}

[1] Irawan, "Penerapan Strategi Pembelajaran Kontekstual untuk Meningkatkan Kemampuan Berpikir Kritis matematika,” Jurnal Ilmu Pendidikan. Vol 22 no 1, 2016.

[2] M. Lloyd and N. Bahr, "Thinking Critically about Critical Thinking in Higher Education," International Journal for the Scholarship of Teaching and Learning, vol. 4, no. 2, 2010.

[3] I.J. Hassoubah, Cara Berpikir Kreatif dan Kritis. Bandung: Nuansa, 2004.

[4] A. Fisher, Critical thinking; an introduction. London: Cambridge UniversityPress. (Buku asli diterbitkan tahun 2007), 2009.

[5] R.H. Ennis, An Annotated List of Critical Thinking Tests Prepared by Robert H. Ennis, University of Illinois, revised July 2006 (at the time of writing this needed updating, but it is nonetheless a useful exposition, 1996.

[6] J.W. Santrock, Psikologi Pendidikan, Edisi Kedua. Jakarta: Kencan, 2011.

[7] E. Jensen, Brain-Based Learning. Yogyakarta: Pustaka Pelajar, 2008.

[8] G. Proulx, "Integrating Scientific Method \& Critical Thinking in Classroom Debates on Environmental Issues," National Association of Biology Teachers. Bio one Reseach, vol. 66, no. 1, 2004.

[9] Erickson, H. Lynn, Lois A. Lanning and Rachel French, Concept-Based Curiculum and Intruction : for the Thinking Classroom Second Edition. Carifornia : Corwin A SAGE Company, 2017.

[10] E.B. Johnson, Contextual Teaching and Learning: What It Is and Why It Is Here to Stay. California USA: Corwin Press. Inc, 2002

[11] E.B. Jhonson, Contextual Teaching and Learning. California: Corwin Press, Inc., 2002.

[12] R.W. Dahar, Teori-Teori Belajar \& Pembelajaran. Jakarta: Erlangga, 2006

[13] P.A. Facione, Critical Thinking : What it is and Why it Counts. Pearson Education : Insight Assessment. Diunduh tanggal 26 Februari 2015. Http://www.insightassessment.com., 2011.

[14] OECD, PISA Result 2018. https://www.oecd.org/pisa/publications/pisa2018-results.htm, 2018.

[15] Trends in International Mathematics and Science Study. https://www.iea.nl/studies/iea/timss/2019, 2019

[16] A. Permanasari, "Penerapan Pembelajaran IPA Terpadu Tipe Threaded dengan Level of Inquuiry untuk Meningkatkan Keterampilan Berpikir Kritis Dan Penguasaan Konsep," Bandung: Jurnal Edusains, vol. 7, no. 2, pp. $143-150,2016$

[17] B. Rubini, B. Septian and Irvan Permana, "Enhancing critical thinking through the science learning on using interactive problem based module,” J. Physics.: Conference. Series. 1157 022001, 2018.

[18] C. Wieman and G. Sarah, "Taking a Scientific Approach to Science Education, Part II - Changing Teaching," Microbe, Volume 10, Number $5,2015 \cdot 203-207,2015$
[19] S. Juwariyah, K. Soepriyono and L. Eny, "Guided Inquiry Method Employing Virtual Laboratory To Improve Scientific Working Skills,' Jurnal Pendidikan Sains Volume 5, Number 1, March 2017, pp. 17-25, 2017.

20] Emiliani, Zulirfan, Fakhruddin, "The Application of Learning With Cognitive Conflict Approach In Improving Understanding Concept of Physics Of Class VIII Students of SMP 40 Pekanbaru," Jurnal Geliga Sains, no. 6, no. 1, pp. 31-38, 2018, 2018

[21] M. Lukitasari, P. Indah, U. Sri and S. Akhmad, "Blended-ProblemBased Learning: How its impact on students' critical thinking skills?," JPBI Jurnal Pendidikan Biologi Indonesia, ol. 5, No. 3, November 2019 , pp. 425-434, 2019.

[22] Parno, Fathurrahman, Asim , P. Suwasono. M. Ali, "The Influence of Problem Based Learning on Critical Thinking Ability for Students in Optical Instrument Topic. Jurnal Pendidikan Fisika Indonesia, vol. 15, no. 1 , pp. 39-45, 2019.

[23] J Afriana, A Permanasari, and A Fitriani, "Project Based Learning Integrated To Stem To Enhance Elementary School's Students Scientific Literacy,” JPII 5 (2) (2016) 261-267 Jurnal Pendidikan IPA Indonesia, 2016

[24] E. Sulistiani, S B Waluya and Masrukan, "The analysis of student's critical thinking ability on discovery learning by using hand on activity based on the curiosity," IOP Publishing IOP Conf. Series: Journal of Physics: Conf. Series, vol. 983 (2018) 012134, 2018

[25] Nurhadi, Pendekatan Kontekstual. Jakarta: Departemen Pendidikan Nasional, 2002

[26] B. Rubini and A. Permanasari, "The Development of Contextual Model with Collaborative Strategy in Basic Science Course to Enhance Students' Scientific Literacy," Journal of Education and Practice, vol. 5, no. 6 , pp. 52-58, 2014

[27] Ferreira, Sousa, Nafalski, Machotka, Nedic, "Collaborative learning based on a micro-webserver remote test controller", Bridgeport, University of South Australia, 2010.

[28] R. Puspita, "Sistem Informasi Aplikasi Virtual Lab Pada Laboratorium Sistem Informasi Universitas Gunadarma," Proceeding, Seminar Ilmiah Nasional Komputer dan Sistem Intelijen (KOMMIT 2008) Auditorium Universitas Gunadarma, Depok, 20-21 Agustus 2008.

[29] J. Schneider, D. Börner, P. Van Rosmalen, and M. Specht, “Augmenting the senses: a review on sensor-based learning support," Sensors, vol. 15 no. 2, pp. 4097-4133.

[30] N. Rizman, Laboratorium virtual in Chemistry - Experimental Study of Understanding, Reproduction and Application of Acquired Knowledge of Subject's Chemical Content Organizacija, Volume 45. Bandung: Rosdakarya, 2015

[31] Manisha, Bajpai and Anil, Kumar, "Effect Of Virtualaboratory On Student Conceptual Achievement In Physics," International Journal of Current Reasearch, Volume 7, issue 02, pp 12808-12813, 2015

[32] J.R. Fraenkel and N.E. Wallen, How to Design and Evaluate Research in Education. Boston : McGraw Hill, 2007.

[33] J.W. Creswell, Reseach Design. Yogyakarta. Pustaka Pelajar, 2016

[34] D.R. Krathwohl, “A Revision of Bloom's Taxonomy: An Overview," Theory Into Practice, Volume 41, Number 4, Autumn 2002, 2002.

[35] H. Salam, A. Setiawan, and I. Hamidah, Pembelajaran Bebasis Vitual Laboratory untuk Meningkatkan Penguasaan Konsep pada Materi Listrik Dinamis. Proc.ICTE - UPI \& UPSI, 2010. 